13. Lamberts SWJ, Bruining HA, deJong FH 1997 Corticosteroid therapy in severe illness. N Engl J Med 337:1285-1292

14. Joosten KFM, De Kleijn ED, Westerterp M, De Hoog M, Eijck FCV, Hop WCJ, Voort EVD, Hazelzet JA, Hokken-Koelega ACS 2000 Endocrine and metabolic responses in children with meningococcal sepsis: striking differences between survivors and nonsurvivors. J Clin Endocrinol Metab 85:3746-3753

15. Rothwell PM, Udwadia ZF, Lawler PG 1991 Cortisol response to corticotropin and survival in septic shock. Lancet 337:1230-1231

16. Soni A, Pepper GM, Wyrwinski PM, Ramirez NE, Simon R, Pina T, Gruenspan H, Vaca CE 1995 Adrenal insufficiency occurring during septic shock: incidence, outcome and relationship to peripheral cytokine levels. Am J Med 98:266-271

17. Mesiano S, Jaffe RB 1997 Developmental and functional biology of the primate fetal adrenal cortex. Endocr Rev 18:378-403

18. al Saedi S, Dean H, Dent W, Cronin C 1995 Reference ranges for serum cortisol and 17-hydroxyprogesterone levels in preterm infants. J Pediatr 126:985-987

19. Lee MM, Rajagopalan L, Berg GJ, Moshang T 1989 Serum adrenal steroid concentrations in premature infants. J Clin Endocrinol Metab 69:1133-1136

20. Hingre RV, Gross SJ, Hingre KS, Mayes DM, Richman RA 1994 Adrenal steroidogenesis in very low birth weight preterm infants. J Clin Endocrinol Metab 78:266-270

21. Huysman MWA, Hokken-Koelega ACS, DeRidder MAJ, Sauer PJJ Adrenal function in sick very preterm infants. Pediatr Res 2000 48:629-633

22. Yoder BA, Martin H, McCurnin DC, Coalson JJ Impaired urinary cortisol excretion and early cardiopulmonary dysfunction in immature baboons. Pediatr Res 51:426432

23. Coalson JJ, Winter VT, Siler-Khodr T, Yoder BA 1999 Neonatal chronic lung disease in extremely immature baboons. Am J Respir Crit Care Med 160:1333-1346

24. Levine A, Cohen D, Zadik Z 1994 Urinary free cortisol values in children under stress. J Pediatr 125:853-857

25. Zadik Z, Amer R, Dolfin Z, Arnon S, Cohen D, Mogilner B, Reifen R 1999 Urinary free cortisol (UFC) values in newborns under stress. J Pediatr Endocrinol Metab 12:543-547

26. Watterberg KL, Scott SM, Backstrom C, Gifford KL, Cook K 2000 Links between early adrenal function and respiratory outcome in preterm infants: airway inflammation and patient ductus arteriosus. Pediatrics 105:320-324

27. Korte C, Styne D, Merritt TA, Mayes D, Wertz A, Helbock HJ 1996 Adrenocortical function in the very low birth weight infant: Improved testing sensitivity and association with neonatal outcome. J Pediatr 128:257-263

28. Huysman MWA, Hokken-Koelega ACS, De Ridder MAJ, Sauer PJJ 2000 Adrenal function in sick very preterm infants. Pediatr Res 48:629-633

29. Watterberg KL, Scott SM 1995 Evidence of early adrenal insufficiency in babies who develop bronchopulmonary dysplasia. Pediatrics 95:120-125
30. Banks BA, Stouffer N, Cnaan A, Ning Y, Merrill JD, Ballard RA, Ballard PL 2001 Association of plasma cortisol and chronic lung disease in preterm infants. Pediatrics 107:494-498

31. Watterberg KL, Gerdes JS, Gifford KL, Lin H-M 1999 Prophylaxis against early adrenal insufficiency to prevent chronic lung disease in premature infants. Pediatrics 104:1258-1263

32. Hillier SL, Krohn MA, Kiviat NB, Watts DH, Eschenbach DA 1991 Microbiologic causes and neonatal outcomes associated with chorioamnion infection. Am J Obstet Gynecol 165:955-961

33. Zlatnik FJ, Gellhaus TM, Benda JA, Koontz FP, Burmeister LF 1990 Histologic chorioamnionitis, microbial infection, and prematurity. Obstet Gynecol 76:355-359

34. Watterberg KL, Demers LM, Scott SM, Murphy S 1996 Chorioamnionitis and early lung inflammation in infants in whom bronchopulmonary dysplasia develops. Pediatrics 97:210-215

35. Yoon BH, Romero R, Jun JK, Park KH, Park JD, Ghezzi F, Kim BI 1997 Amniotic fluid cytokines (interleukin-6, tumor necrosis factor- $\alpha$, interleukin- $1 \beta$, and interleukin-8) and the risk for the development of bronchopulmonary dysplasia. Am J Obstet Gynecol 177:825-830

36. Yoon BH, Jun JK, Romero R, Park KH, Gomez R, Choi JH, Kim IO 1997 Amniotic fluid inflammatory cytokines (interleukin-6, interleukin-1beta, and tumor necrosis factor-alpha), neonatal brain white matter lesions, and cerebral palsy. Am J Obstet Gynecol 177:19-26

37. Yanowitz T, Jones J, Gilmour C, Jordan J, Brozanski B 2000 Cytokine-associated hemodynamic alterations in low birth weight infants born to mothers with chorioamnionitis. Pediatr Res 47:441A

38. Finkel MS, Hoffman RA, Shen L, Oddis CV, Simmons RL, Hattler BG 1993 Interleukin-6 as a mediator of stunned myocardium. Am J Cardiol 71:1231-1232

39. Briegel J, Jochum M, Gippner-Steppert C, Thiel, M 2001 Immunomodulation in septic shock: hydrocortisone differentially regulates cytokine responses. J Am Soc Nephrol 12:S70-S74

40. Orth DN, Kovacs WJ, DeBold RC 1992 The adrenal cortex. In: Wilson JD, Foster DW, (eds) Williams Textbook of Endocrinology, 8th Ed. W.B. Saunders, Philadelphia, pp 489-620

41. Sloviter RS, Valiquette G, Abrams GM, Ronk EC, Sollas AL, Paul LA, Neubort S 1989 Selective loss of hippocampal granule cells in the mature rat brain after adrenalectomy. Science 243:535-538

42. Halliday HL, Ehrenkranz RA 2000 Early postnatal ( $<96$ hours) corticosteroids for preventing chronic lung disease in preterm infants (Cochrane Review) In: The Cochrane Library, Issue 4. Oxford: Update Software

\title{
SSRIs in Pregnancy -Are they safe?
}

\section{Commentary on the articles by Oberlander et al. on page 443 and Morrison et al. on page 433}

\author{
GIDEON KOREN
}

The Motherisk Program, The Hospital for Sick Children and University of Toronto, 555 University Avenue, Toronto, Ontario, M5G 1 X8 Canada

An estimated $10 \%$ to $20 \%$ of women of reproductive age suffer from depression, often necessitating pharmacotherapy. During the last decade, there has been a dramatic shift in the treatment of patients with depression, with the selective serotonin reuptake inhibitors (SSRIs) largely replacing the tricyclic antidepressants. Typical of drug development, fluoxetine entered the market with reassuring animal reproductive studies but with no human experience. Because at least half of all pregnancies are unplanned, coupled with physicians and patients often being reluctant to discontinue effective drug therapy, postmarketing studies have gradually emerged on the safety of fluoxetine in pregnancy. Such studies have not shown evidence of morphologic or functional teratogenicity of fluoxetine (1-4).

Many women cannot discontinue their antidepressant therapy in pregnancy without a major negative impact on their well being. Einarson et al. have recently documented that "cold turkey" discontinuation of SSRIs and other psychotropic drugs in preg- nancy can lead to substantial morbidity among women, including suicide ideation, hospitalization, and replacement of medications with alcohol (5). Hence, it is most important that the assessment of safety of medications in human pregnancy includes careful evaluation of the maternal and fetal risks of the untreated condition. A recently completed study of pregnancy outcome among children of women taking fluoxetine throughout pregnancy has failed to show any adverse effects on birth weight, preschool IQ, language development, or behavior. The study did find that the maternal level of depression (and not fluoxetine) is negatively associated with measures of child development (6).

This issue of Pediatric Research contains two studies from the University of British Columbia dedicated to the effects of SSRIs in pregnancy $(7,8)$. One study uses sheep as a model for physiologic changes associated with fluoxetine (7). The second study investigated neonatal pain response associated with SSRIs and benzodiazepines in pregnancy (8). 
In their meticulous and well-planned study, Morrison and colleagues (7) detected an acute, but transient effect on uterine blood flow, temporally related to i.v. infusion of fluoxetine. They also monitored blood gases and fetal growth. Animal studies are critical in advancing our understanding of mechanisms of potential fetal or placental pathology. The chronically cannulated sheep model is an important experimental paradigm in establishing mechanisms of fetal safety and placental transfer. With this model one can bridge gaps of knowledge which cannot be obtained ethically in human pregnancy. Yet, before extrapolating such results to humans, one has to acknowledge differences between the experimental design in the animal, and human physiology and pharmacology. Morrison and colleagues should be commended for exhibiting remarkable caution in extrapolating their results with existing human data.

Although the measured long-term (steady state) serum concentrations of fluoxetine and its active metabolite in the sheep were in the range observed in treated patients, the acute observed effects may be related to the i.v. bolus of the drug, which results in high initial serum concentrations falling rapidly, typical of the distribution phase of most drugs. Because women do not receive fluoxetine as an i.v. bolus, it is difficult to decide whether the acute observed effects can be expected in humans. Due to the very long elimination half-life of fluoxetine, and the lack of a loading dose in humans, serum concentrations accumulate slowly over months, possibly avoiding the bolus effect seen in the present animal study. To mimic the human clinical pharmacology of fluoxetine, it will be interesting to repeat a similar protocol, but with oral administration of the drug, or with an infusion rate that avoids the bolus effect, allowing the slow accumulation of fluoxetine.

Oberlander and colleagues investigated the effects of SSRIs and benzodiazepines in pregnancy on neonatal pain response (8). Using a validated tool for measurement of pain response in neonates, they have shown an apparently attenuated pain response in babies exposed in utero to a variety of psychoactive drugs when compared with an unexposed control group. This is the first study to assess pain response in neonates as related to their prenatal drug exposure. It is also the first study to explore potential alterations in sensory functions following in utero exposure to SSRIs with or without benzodiazepines. Hence, the ramifications of this study may be far-reaching. If prenatal exposure to SSRIs or benzodiazepines affect neuronal development, then one needs to be very restrictive in their use, even beyond first trimester embryogenesis.

However, before such effects can be inferred, future work will have to address the possibility that what Oberlander and colleagues observed is a direct neonatal drug effect. The authors report that all women took their psychotropic drugs up to birth and during the first few days of breastfeeding. Benzodiazepines and SSRIs have much longer elimination half lives in the neonate than in the mother, and hence all neonates likely had clinically significant levels at the time of measurement of pain response. Without measuring directly the concentrations of these drugs in the neo- nate, it may not be possible to conclude that these psychoactive drugs affect intrauterine "wiring" of neurons.

A possible way to separate potential in utero effects on CNS development versus direct postnatal pharmacological effects would be through correlation of serum drug concentrations in the neonate and attenuation of pain response, and/or changes in autonomic responses.

Should these studies lead to changes in the way one counsels pregnant women about safety of SSRIs in pregnancy? I do not believe so. One of the studies reported transient changes in uterine blood flow after IV bolus of fluoxetine, a schedule not used in humans. The other study described changes in pain response that may well be caused by direct pharmacological effects on the newborn. It is critical that these two important studies be read in their context, and not interpreted separately as proofs of increased fetal risks. Two years ago Pediatric Research published experiments in chick embryos showing inhibition of NMDA receptors by dextromethorphan (9). Much publicity ensued (10), and unnecessary havoc was caused for thousands of women and their health providers. Not surprisingly, epidemiologic human studies that followed, have failed to show increased human risks $(11,12)$.

One has to be very careful when incorporating research findings into the reproductive risk-benefit equation. New findings should not be looked independently, but rather within the context of all available data, and this will create the appropriate balance in their interpretation.

Acknowledgments. GK is a Senior Scientist of the Canadian Institutes for Health Research. Supported by The Research Leadership in Better Pharacotherapy During Pregnancy and Lactation.

\section{REFERENCES}

1. Addis A, Koren G 2000 Safety of fluoxetine during the first trimester of pregnancy: a meta-analytical review of epidemiological studies. Psychol Med 30:89-94

2. Koren G, Nulman I, Addis A 1998 Outcome of children exposed in utero to fluoxetine: a critical review. Depress Anxiety 8(suppl 1):27-31

3. Kulin NA, Pastuszak A, Koren G 1998 Are the new SSRIs safe for pregnant women? Can Fam Physician 44:2081-2083

4. Nulman I, Rovet J, Stewart DE, Wolpin J, Gardner HA, Theis JG, Kulin N, Koren G 1997 Neurodevelopment of children exposed in utero to antidepressant drugs. N Engl J Med 23:336(4):258-262

5. Einarson A, Selby P, Koren G 2001 Abrupt discontinuing of psychotropic drugs during pregnancy: Fear of teratogenic risk and impact of counselling. J Psychiatry Neurosci 26:44-48

6. Nulman I, Rovet J, Stewart D, Wolpin J, Loebstein M, Pace Asciak P, Fried S, Koren G 2001 Neurodevelopment of children exposed to maternal antidepressant drugs throughout gestation: A prospective controlled study. Clin Pharmacol Ther 69:31

7. Morrison JL, Chien C, Riggs KW, Gruber N, Rurak D 2002 Effect of maternal fluoxetine administration on uterine blood flow, fetal blood gas status, and growth. Pediatr Res 51:433-442

8. Oberlander TF, Grunau RE, Fitzgerald C, Ellwood AL, Misri S, Rurak D, Riggs W 2002 Prolonged prenatal psychotropic medication exposure alters neonatal acute pain response. Pediatr Res 51:443-453

9. Andaloro VJ, Moraghan DT, Rosenquist TH 1998 Dextromethorphan and other $\mathrm{N}$-methyl-D-aspartate receptor antagonists are teratogenic in the avian embryo model. Pediatr Res 43:1-7

10. Associated Press 1998 Pregnant women urged to shun cough remedies. Toronto Star, January 17

11. Martinez-Frias ML, Rodriguez-Pinilla E 2001 Epidemiologic analysis of prenatal cough medicines containing dextromethorphan: No evidence of human teratogenicity. Teratology 63:38-41

12. Einarson A, Lyskiewicz D, Koren G 2001 The safety of dextromethorphan in pregnancy. Chest 119:466-469 